\title{
Política, poder e comunicação em Debord e Arendt
}

\section{Politics, power and communication in Debord and Arendt}

Claudio Novaes Pinto Coelho ${ }^{1}$ 


\section{Resumo}

Guy Debord é reconhecido como o principal teórico da sociedade do espetáculo, além de ter sido também um importante militante político e agitador cultural. O artigo aqui apresentado, fruto de uma pesquisa de Pós-Doutorado, procura compreender os conceitos de poder deste autor e como eles estão relacionados com o seu projeto de transformação revolucionária da sociedade capitalista. Tendo em vista este objetivo, será realizada uma análise comparativa com o pensamento de Hannah Arendt, reconhecida como uma das mais significativas autoras do século XX e que também desenvolveu reflexões sobre temas presentes nos textos e na atuação de política e cultural de Debord.

Palavras-chave

Diálogo, poder, revolução, totalitarismo.

\section{Abstract}

Guy Debord is acknowledged as the leading theoretician of spectacle society and an important political activist and cultural agitator. This paper presents the result of a postdoctoral research, and analyzes the concepts of power presented by this author and how they are related to his project of revolutionary transformation of capitalist society. For such, a comparative analysis was performed with the thought of Hannah Arendt, one of the most significant authors of the twentieth century, who also reflected on themes present in Debord's texts and political and cultural action.

\section{Keywords}

Dialogue, power, revolution, totalitarianism. 
O artigo faz parte de uma pesquisa de Pós-Doutorado cujo objetivo principal é a compreensão dos conceitos de espetáculo e de poder de Guy Debord e da possibilidade destes conceitos serem úteis para o entendimento da sociedade contemporânea. Pretende-se, aqui, refletir sobre as relações entre poder e comunicação e entre espaços públicos, comunicação e revolução em Debord, que, longe de ser pura e simplesmente o teórico da sociedade do espetáculo, era alguém que procurava impulsionar uma transformação revolucionária da sociedade capitalista. Para auxiliar esta reflexão será realizada uma análise comparativa entre as concepções desse autor e as concepções de Hannah Arendt, pensadora e analista política vinculada a correntes teóricas e políticas distintas das de Debord, mas que também refletiu sobre temas trabalhados por ele. Esta análise comparativa, além de colaborar para uma melhor compreensão do pensamento de Debord, também é útil para ressaltar a importância do seu pensamento como um autor da mesma estatura de Hannah Arendt, reconhecida como uma das mais importantes pensadoras do século XX.

Para Debord, a possibilidade de superação das formas de poder presentes na sociedade do espetáculo depende de uma comunicação dialógica, que seria o principal elemento de uma organização política verdadeiramente revolucionária, e do exercício do poder pelos conselhos operários na sociedade pós-capitalista. O momento inicial da comparação entre Debord e Arendt será um confronto entre as posições destes autores, no que diz respeito à relação entre os conselhos operários e a comunicação dialógica, mas a comparação requer um aprofundamento de vários aspectos do pensamento/ação de Debord. Antes de mais nada, há a necessidade de entendimento da sua visão sobre a linguagem.

\section{Linguagem e cultura em Debord}

A abordagem de Debord sobre a questão da linguagem, que é fundamental para a compreensão da sua visão da questão do diálogo, passa pela dimensão histórica. Sem dúvida, trata-se de uma visão sobre a história que é devedora das concepções de Hegel e Marx sobre a dimensão dialética do processo histórico. 
A linguagem é pensada por ele dentro de uma reflexão sobre a dimensão histórica da cultura, de modo geral, e da arte, em particular:

O desenvolvimento dos conhecimentos da sociedade, que contém a compreensão da história como o cerne da cultura, adquire por si um conhecimento sem retorno, expresso pela destruição de Deus. Mas essa "condição primeira de toda crítica" é também a obrigação primeira de uma crítica infinita. (DEBORD, 1997, p. 120)

Pensar a dimensão histórica da cultura é, para Debord, refletir sobre a dialética entre separação/não separação. Uma questão absolutamente central para o seu pensamento/ação. A existência da cultura está vinculada, de acordo com argumentos desenvolvidos principalmente no capítulo VIII do livro Sociedade do espetáculo, à existência da divisão social do trabalho, que separou o trabalho manual do trabalho intelectual: aspecto decisivo para a separação entre as classes sociais, e que significou a superação da chamada comunidade primitiva, na qual a vida social era baseada na presença de uma linguagem comum, de fundo mítico:

A cultura é a esfera geral do conhecimento e das representações do vivido, na sociedade histórica dividida em classes; o que equivale a dizer que ela é o poder de generalização que existe à parte, como divisão do trabalho intelectual e trabalho intelectual da divisão. A cultura se desligou da unidade típica da sociedade do mito. (DEBORD, 1997, p. 119, grifo do autor)

Há um vínculo direto entre a cultura e a separação que passa a existir no interior da vida social com a divisão do trabalho. Mas, dialeticamente, a cultura, no seu desenvolvimento histórico, pode servir para a crítica dessa separação, pois ela é considerada como o lugar da busca da unidade perdida:

A história, que cria a autonomia relativa da cultura e as ilusões ideológicas a respeito dessa autonomia, também se expressa como história da cultura. E toda história da vitória da cultura pode ser compreendida como a história da revelação da sua insuficiência, como uma marcha para sua auto-supressão. A cultura é o lugar da busca da unidade perdida. Nessa busca da unidade, a cultura como esfera separada é obrigada a negar a si própria. (DEBORD, 1997, p. 119-120) 
A superação da sociedade do espetáculo, com a autossupressão da cultura, significaria a recriação de uma linguagem comum. No entanto, não seria pura e simplesmente, como aponta João Emiliano de Aquino (2006), um retorno à linguagem comum do mito:

Em outras palavras, Debord concebe criticamente a existência histórica de uma linguagem comum nas sociedades pré-capitalistas, entendida como linguagem comum da tradição, portanto, como expressão das "forças que freiam o movimento" [...], como domínio do passado sobre o presente ou, se se quiser, como linguagem arcaica. Esta linguagem está "perdida" também no sentido de que é irretornável. (AQUINO, 2006, p. 130)

A recriação de uma linguagem comum, com a transformação revolucionária da sociedade do espetáculo, é um processo inédito; posto que seria baseado em uma consciência histórica, ainda não efetivada como tal. Ainda de acordo com João Emiliano de Aquino:

Debord, portanto, nomeia duas experiências históricas bem diversas a "comunidade inativa" pré-capitalista e a "real comunidade histórica" comunista a vir - sob o mesmo signo da linguagem comum. (AQUINO, 2006 , p. 130, grifo do autor)

Para Debord, dentro da cultura, é a produção artística que desenvolve, por intermédio de um processo histórico que vai do barroco à arte moderna, uma ação decisiva para a destruição da antiga linguagem comum e para a recriação, em novas bases, de uma linguagem comum. A arte moderna, ao apontar para uma indistinção entre vida e arte, mediante a autodissolução da arte, cria as condições para a recriação da linguagem comum e para a efetivação de uma comunicação dialógica:

A linguagem da comunicação está perdida - eis o que expressa positivamente o movimento de decomposição moderna de toda a arte, seu aniquilamento formal. $O$ que esse movimento expressa negativamente é o fato de uma linguagem comum ter de ser reencontrada [...]. Essa linguagem precisa ser reencontrada na práxis, que reúne em si a atividade direta e sua linguagem. Trata-se de possuir efetivamente a comunidade 
do diálogo e o jogo com o tempo que foram representados pela obra poético-artística. (DEBORD, 1997, p. 122, grifo do autor)

Ao valorizar a práxis, Debord defende a não separação entre linguagem e ação e a presença de uma dimensão lúdica/estética na comunicação dialógica. De maneira coerente com essa postura, em 1968, o movimento situacionista defendia a formação de conselhos operários e utilizava uma linguagem com componentes poéticos, como nos slogans pichados nas paredes da cidade de Paris e presentes nos cartazes de divulgação do movimento.

A não separação entre cultura e política, com a defesa de uma não separação entre o lúdico e a vida cotidiana, estava presente na práxis situacionista desde o seu primeiro momento, como se pode perceber por um texto sobre o jogo publicado no primeiro número da revista da Internacional Situacionista (2003, p. 60):

O elemento de competição deve desaparecer em favor de um conceito mais realmente coletivo de jogo: a criação comum das ambiências lúdicas escolhidas. A distinção central a superar é a que se estabelece entre jogo e vida corriqueira, considerando-se o jogo como uma exceção isolada e provisória.

\section{Diálogo e política segundo Arendt e Debord}

Hannah Arendt também defende a comunicação dialógica em espaços públicos e o vínculo linguagem/ação. Para ela, a política é inseparável do exercício da liberdade para criar o que ainda não existe: o novo. Há, para essa autora, uma diferenciação entre a dimensão econômica dos processos de trabalho, voltada para o fabricar, e a ação política marcada pela ação. Nas palavras de Eduardo Jardim (2011, p. 85):

Sob muitos aspectos, a teoria da ação de Hannah Arendt pôs em evidência o contraste entre as atividades do fazer e do agir: ao sublinhar a diferença entre o modo de ser previsível do fazer e a imprevisibilidade, até o ponto do milagre, da ação; ao distinguir o modo de intervenção do trabalho, que sempre depende de uma matéria dada e de instrumentos para alcançar um resultado, do poder inaugural de iniciar processos, característico do agir. 
Liberdade e ação política são inseparáveis, em Arendt, de uma valorização da individualidade: "Porque destruir a individualidade é destruir a espontaneidade, a capacidade do homem iniciar algo novo com seus próprios recursos, algo que não possa ser explicado à base de reação ao ambiente e aos fatos" (ARENDT, 1989, p. 506).

A valorização da individualidade está presente na maneira como Arendt entende o vínculo entre ação e discurso:

Na ação e no discurso, os homens mostram quem são, revelam ativamente suas identidades pessoais e singulares, e assim apresentam-se ao mundo humano, enquanto suas identidades físicas são reveladas, sem qualquer atividade própria, na conformação singular do corpo e no som singular da voz. Esta revelação de "quem", em contraposição a "o que" alguém é os dons, qualidades, defeitos que alguém pode exibir ou ocultar - está implícita em tudo o que se diz ou faz. (ARENDT, 1981, p. 192)

A identificação entre política, liberdade e individualidade, estabelecida por Arendt, é inseparável da sua defesa da cidade-estado grega como modelo de espaço público, devido à separação entre o público e o privado:

Segundo o pensamento grego, a capacidade humana de organização política não apenas difere mas é diretamente oposta a essa associação natural cujo centro é constituído pela casa (oikia) e pela família. O surgimento da cidade-estado significava que o homem recebera "além da sua vida privada, uma espécie de segunda vida, o seu bios politikos. Agora cada cidadão pertence a duas ordens de existência; e há uma grande diferença em sua vida entre aquilo que lhe é próprio (idion) e o que é comum (koinom)". (ARENDT, 1981, p. 33)

A separação entre o econômico - marcado pela dimensão do fabricar (fazer) - e o político - caracterizado pelo agir - está presente na defesa que Arendt faz dos conselhos operários. Para ela, o fracasso dos conselhos operários na revolução russa de 1917 está relacionado

à tentativa de misturar o econômico com o político, devido à proposta de que os conselhos operários deveriam gerir a economia, administrando as fábricas. De acordo com Arendt, os conselhos são órgãos de ação, não de administração: 
O erro fatal dos conselhos foi que eles próprios nunca fizeram uma distinção muito nítida entre participação nos negócios públicos e administração ou gestão de coisas de interesse público. No âmbito de conselhos de trabalhadores, eles tentaram, repetidas vezes, assumir a gerência das fábricas, e todas essas tentativas redundaram em fragorosos fracassos. [...] Os conselhos das fábricas introduziram um componente de ação na gerência das coisas, e isso, na verdade, só podia gerar o caos. (ARENDT, 1988, p. 218-219)

A separação entre o econômico e o político não faz sentido dentro do pensamento de Debord, ainda que ele e Arendt compartilhem a crítica ao papel desempenhado pelos partidos políticos. Debord critica a presunção dos partidos, principalmente de partidos ditos proletários, de representarem as classes sociais. Este é um componente, segundo ele, essencial para a existência da sociedade do espetáculo. Arendt também postula a oposição, no interior dos processos revolucionários, entre os partidos e os conselhos operários:

O conflito entre os dois sistemas, o de partidos e o de conselhos, veio à tona em todas as revoluções do século XX. O problema em causa era a representação versus ação e participação. Os conselhos eram órgãos de ação, os partidos revolucionários eram órgãos de representação, e, embora os partidos revolucionários relutantemente reconhecessem os conselhos como instrumentos de "luta revolucionária", eles tentaram, mesmo em meio à revolução, controlá-los a partir de dentro; eles sabiam muito bem que nenhum partido, por mais revolucionário que fosse, poderia sobreviver à transformação do governo numa verdadeira república soviética. (ARENDT, 1988, p. 218)

Mas, para Debord, não é apenas a separação entre o econômico e o político que não faz sentido dentro de um processo revolucionário, a cultura também não pode ser vista como uma realidade separada. O processo revolucionário deveria reinventar os próprios processo de trabalho, mediante a transformação das fábricas em espaços públicos, e a presença de uma dimensão lúdica, com a valorização permanente da criatividade. É nesse contexto que aconteceria a criação de uma nova linguagem comum.

De uma perspectiva arendtiana, nada disso faz sentido. No entanto, o pensamento de Arendt pode servir para uma problematização da visão de Debord 
sobre a sociedade pós-capitalista. Debord valoriza a dimensão histórica da cultura que levaria à sua autossupressão e a uma noção de temporalidade marcada pelo tempo irreversível, que seria a base para um exercício permanente da criatividade, em um contexto social, o do exercício do poder pelos conselhos operários, onde não haveria mais separação entre o econômico, o político e o cultural. Hannah Arendt, por sua vez, não só separa o econômico do político, como separa o artístico do político. Para ela a arte está vinculada à dimensão do fazer, enquanto a política diz respeito à ação:

No sentido das artes criativas, que põem em cena alguma coisa tangível e que reificam o pensamento humano a tal ponto que as coisas produzidas possuem existência própria, a política é o exato oposto de uma arte - o que não significa, aliás, que ela seja uma ciência. As instituições políticas não importa quão bem ou quão mal sejam projetadas - dependem, para sua existência permanente de homens de ação, e sua conservação é obtida pelos mesmos meios que as trouxeram à existência. A existência independente identifica a obra de arte como um produto do fazer; a total dependência de atos posteriores para mantê-lo em existência caracteriza o Estado como um produto da ação. (ARENDT, 1979, p. 200)

No entanto, Arendt estabelece uma distinção entre arte de criação, objetivada em obras, e a artes de realização, vinculadas a uma performance e que teriam um vínculo com a política:

As artes de realização, pelo contrário, têm com efeito uma grande afinidade com a política. Os artistas executantes - dançarinos, atores, músicos e o que valha - precisam de uma audiência para mostrarem seu virtuosismo, do mesmo modo como os homens que agem necessitam da presença de outros ante os quais possam aparecer; ambos requerem um espaço publicamente organizado para sua "obra", e ambos dependem de outros para o desempenho de si. (ARENDT, 1979, p. 201)

A dimensão política do situacionismo, afirmada por Debord, parece corroborada pelos argumentos de Arendt; no entanto, estes mesmos pontos de vista problematizam a aproximação do situacionismo, com a sua dimensão lúdica de criação de situações, com o processo de produção fabril, que resulta em obras concretas, materializadas. Para Debord, em arrigo publicado por ele 
na revista da Internacional Situacionista: "A produção central de um trabalho industrial inteiramente reconvertido provocará o arranjo de novas configurações da vida cotidiana, a criação livre de acontecimentos" (DEBORD, 2003, p. 152).

Com base no pensamento de Arendt, conforme, por exemplo, os argumentos sobre os conselhos operários, não há como introduzir o componente da ação permanente, da criação constante no processo de fabricação de objetos.

De todo modo, a revolução pretendida por Debord e pelos situacionistas em maio de 1968 na França não se efetivou, acontecendo, como ele mesmo reconheceu nos Comentários sobre a sociedade do espetáculo, redigidos ao final da década de 1980, um fortalecimento da sociedade do espetáculo, com o surgimento de uma forma de poder que unificou as formas anteriormente existentes: o poder espetacular concentrado e o difuso.

Para Debord, durante o período que vai década de 1920 à década de 1970, dentro do contexto mundial da divisão entre os países capitalistas, e para ele nunca houve efetivamente países socialistas, em função dos diferentes graus de desenvolvimento das forças produtivas existiu a convivência entre as formas concentrada e difusa do poder espetacular.

O poder espetacular concentrado era a forma de poder dos países capitalistas menos desenvolvidos, marcados pela presença de regimes ditatoriais com diferentes características, como o nazifascismo ou o stalinismo, mas onde predominava a presença de "líderes da nação", que concentravam em torno de si a produção do espetáculo e o controle da vida social. Debord entende o poder espetacular concentrado como o elemento principal dos países descritos por ele como "capitalismo burocrático", cuja base é a apropriação coletiva da economia pelos burocratas: "De fato, a propriedade está concentrada, no sentido em que o burocrata individual só tem relação com a posse da economia global por intermédio da comunidade burocrática, como membro dessa comunidade" (DEBORD, 1997, p. 42).

Por intermédio da propriedade burocrática, a burocracia controla o processo de produção e distribuição das mercadorias: "A produção de mercadorias, ali menos desenvolvida, também se apresenta sob uma forma concentrada; a mercadoria 
que a burocracia controla é o trabalho social total, e o que ela revende à sociedade é a sobrevivência como um todo" (DEBORD, 1997, p. 42-43).

À concentração de poder pela burocracia corresponde o exercício da violência e o esvaziamento total da individualidade:

A ditadura da economia burocrática não pode deixar às massas exploradas nenhuma margem significativa de escolha, pois ela teve de escolher tudo. Qualquer outra escolha que Ihe seja exterior, referente à alimentação ou à música, representa a escolha de sua destruição completa. Essa ditadura tem que ser acompanhada de violência permanente. (DEBORD, 1997, p. 43)

Nesse caso, o poder se concentra em torno da imagem da figura do líder, que é a vedete (celebridade) para quem toda a sociedade deve direcionar o seu olhar:

\begin{abstract}
A imagem imposta do bem, em seu espetáculo, recolhe a totalidade do que existe oficialmente e concentra-se normalmente num só homem, que é a garantia da coesão totalitária. Com essa vedete absoluta é que todos devem identificar-se magicamente, ou desaparecer. (DEBORD, 1997, p. 43)
\end{abstract}

Nos países capitalistas mais desenvolvidos, como os EUA, os países da Europa Ocidental e o Japão, vigorava a forma difusa do poder espetacular, marcada por um poder exercido pelas grandes empresas capitalistas sobre a vida cotidiana. Nesta forma de poder, os indivíduos perdem o controle sobre as suas próprias vidas, mais isto não ocorre devido a um poder concentrado pelo aparelho de estado. O uso do tempo é expropriado pelas corporações empresariais e marcado pela produção e o consumo de mercadorias que, na sociedade do espetáculo, está associada à produção e ao consumo de imagens.

A partir da década de 1980, com a derrota das tentativas de transformação revolucionária, que aconteceram em diferentes países a partir do movimento de maio de 1968, e com o enfraquecimento das formas de poder espetacular concentrado, houve o fortalecimento da sociedade do espetáculo nos países mais desenvolvidos e o crescimento da presença dos elementos típicos da sociedade 
do espetáculo nos países menos desenvolvidos. Ocorreu assim, para Debord, em escala mundial, a formação de uma única maneira de exercício do poder espetacular, o poder espetacular integrado. De acordo com o autor:

\begin{abstract}
O espetacular integrado se manifesta como concentrado e difuso, e, desde essa proveitosa unificação, conseguiu usar mais amplamente os dois aspectos. $\mathrm{O}$ anterior modo de aplicação destes mudou bastante. No lado concentrado, por exemplo, o centro diretor tornou-se oculto: já não se coloca aí um chefe conhecido, nem uma ideologia clara. No lado difuso, a influência espetacular jamais marcara tanto quase todos os comportamentos e objetos produzidos socialmente. Porque o sentido final do espetacular integrado é o fato de ele ter se integrado na própria realidade à medida que falava dela e de tê-la reconstruído ao falar sobre ele. Agora essa realidade não aparece diante dele como coisa estranha. (DEBORD, 1997, p. 173)
\end{abstract}

Debord argumenta que, com o poder espetacular integrado, há um uso mais amplo das formas anteriores de poder. Mas ele argumenta que existem algumas especificidades neste processo de integração, aspectos como a existência de um único líder político nos contextos nacionais e a atuação de ideologias claras, que são características do poder concentrado, estariam ausentes do poder espetacular integrado, já que, neste caso, elementos do poder difuso estariam mais fortes.

No entanto, nos últimos anos estamos assistindo a uma presença cada vez maior de elementos ditatoriais nos sistemas políticos de diferentes países, com lideranças políticas que ocupam o poder de forma permanente ou procuram fazer com que isto aconteça, existindo também o crescimento de correntes políticas totalitárias inspiradas no nazifascismo. Por outro lado, estamos vivendo também o crescimento do poder exercido pelas grandes corporações sobre a vida cotidiana, com a mercantilização de todas as dimensões da vida humana. Uma comparação entre os conceitos de poder espetacular de Debord e os conceitos de totalitarismo e de poder de Arendt é extremamente importante, tendo em vista a possibilidade de entendimento da contemporaneidade. 


\section{Totalitarismo e poder em Arendt e Debord}

Tanto Debord quanto Arendt analisam o nazifascismo e o stalinismo como manifestações políticas totalitárias. Evidentemente, Arendt não trabalha com a questão do capitalismo de estado (burocrático) presente em Debord. Para ela, o que deve ser ressaltado é a especificidade do totalitarismo como regime político. Ele promove uma ruptura com a tradição do pensamento político ocidental e se baseia no esvaziamento do fundamento do espaço público: o senso comum e as experiências humanas concretas.

No totalitarismo há uma substituição do senso comum por um processo de "superideologização". Nazifascismo e stalinismo produzem "explicações" para todas as dimensões da existência humana:

Acima da insensatez da sociedade totalitária, entrona-se o ridículo supersentido da sua superstição ideológica. [...]

É principalmente em benefício desse supersentido, em benefício da completa coerência, que se torna necessário ao totalitarismo destruir todos os vestígios do que comumente chamamos de dignidade humana. Pois o respeito à dignidade humana implica o reconhecimento de todos os homens ou de todas as nações como entidades, como construtores de mundo ou co-autores de um mundo comum. Nenhuma ideologia que vise à explicação de todos os eventos históricos do passado e o planejamento de todos os eventos futuros pode suportar imprevisibilidade que advém do fato de que os homens são criativos, de que podem produzir algo novo que ninguém jamais previu. (ARENDT, 1989, p. 509-510)

A disseminação de fórmulas prontas esvazia a capacidade de os indivíduos criarem suas próprias visões da realidade, criarem algo novo, e, mediante a atuação em espaços públicos, construírem um senso comum. Ideologia totalitária e poder totalitário são indissociáveis: "É da própria natureza dos regimes totalitários exigir o poder ilimitado. Esse poder só é conseguido se literalmente todos os homens, sem exceção, forem totalmente dominados em todos os aspectos da vida" (ARENDT, 1989, p. 507).

Se, ao contrário de Debord, Arendt não estabelece relações entre o modo de produção capitalista e o totalitarismo, ambos enfatizam a importância da ideologia 
e o esvaziamento da individualidade. Debord trabalha com o contraponto entre a consciência de classe e a ideologia; o que, sem dúvida, não é o caso em Arendt. Por outro lado, uma visão negativa da ideologia, com base em uma oposição entre as representações ideológicas e as experiências humanas concretas está presente, ainda que em contextos teóricos distintos, em ambos os autores.

A existência da sociedade do espetáculo está justamente vinculada à separação representação/experiência humana concreta: "Toda a vida das sociedades nas quais reinam as modernas condições de produção se apresenta como uma imensa acumulação de espetáculos. Tudo o que era vivido diretamente tornou-se uma representação" (DEBORD, 1997, p. 13, grifo do autor).

Um dos elementos essenciais da distinção entre poder espetacular difuso e concentrado está no caráter da relação entre as representações a experiência: trata-se de dois tipos distintos de representação ideológica. No caso do poder espetacular concentrado, a ideologia possui uma pretensão totalizante, que é encarnada pela figura do "líder" em torno do qual se dá a produção do espetáculo pela burocracia estatal. Na linguagem de Arendt, seria a superideologia produtora de um supersentido. No que diz respeito ao poder espetacular difuso, a ideologia é produzida de forma descentralizada pelas diferentes empresas e reproduz as próprias características da sociedade capitalista, estando vinculada ao universo do consumo. Para Arendt, o que se opõe à ideologia é o senso comum, enquanto para Debord é a consciência de classe e sua concretização efetiva nos conselhos operários e na comunicação ativa. Para ele, o poder dos conselhos operários:

\footnotetext{
É o lugar onde as condições objetivas da consciência histórica estão reunidas; a realização da comunicação direta ativa, na qual terminam a especialização, a hierarquia e a separação, na qual as condições existentes foram transformadas "em condições de unidade". Aqui o sujeito proletário pode emergir da sua luta contra a contemplação: sua consciência é igual à organização prática que ela mesma se propôs, porque essa consciência é inseparável da intervenção coerente na história. (DEBORD, 1997, p. 82, grifo do autor)
}

Os conselhos operários representam a superação do poder espetacular, com a sua separação entre representação ideológica e a experiência real. Tendo em vista 
a dimensão comunicacional do poder dos conselhos operários e por se tratar de um exercício de poder desvinculado da dominação de classes, a visão de Debord sobre este tipo de poder pode ser aproximada da concepção arendtiana de poder.

Habermas chama atenção para a dimensão comunicacional presente nesta concepção de poder, mencionando o seu vínculo com a combinação entre ação e discurso: "H. Arendt desprende o conceito de poder do modelo teleológico da ação, o poder se constitui na ação comunicativa, é um efeito coletivo da fala, na qual o entendimento mútuo é um fim em si para todos os participantes" (HABERMAS, 1980, p. 103).

Por outro lado, a separação conceitual estabelecida por Arendt entre poder e violência não está, evidentemente, presente em Debord. Estamos diante, antes de mais nada, de uma diferença metodológica. Enquanto ele trabalha com a dialética e a unidade dos contrários numa totalidade histórica, Arendt trabalha com uma metodologia de base kantiana, e que nas ciências sociais está presente, por exemplo, em Max Weber, de separação epistemológica entre as várias dimensões do real.

Ainda que Arendt reconheça que nas suas manifestações concretas poder e violência costumem estar presentes simultaneamente, ela as diferencias conceitualmente: "Poder e violência, ainda que fenômenos distintos, quase sempre aparecem juntos. Onde quer que estejam associados, o poder, como temos verificado, é o fator principal e predominante" (ARENDT, 1973, p. 129). Para ela, o poder está relacionado à capacidade humana de agir de comum acordo:

Poder corresponde à capacidade humana não somente de agir mas de agir de comum acordo. O poder nunca é propriedade de um indivíduo; pertence a um grupo e existe somente enquanto o grupo se conserva unido. Quando dizemos que alguém está "no poder", queremos dizer que está autorizado por um certo número de pessoas a atuar em nome delas. (ARENDT, 1973, p. 123)

Debord articula poder, espetáculo e dominação de classes: 
responde por todas as outras. É a representação diplomática da sociedade hierárquica diante de si mesma, na qual toda outra fala é banida. No caso, o mais moderno é também o mais arcaico. (DEBORD, 1997, p. 20)

No entanto, ele parece reconhecer a possibilidade de um poder desvinculado da violência e da dominação espetacular, o poder dos conselhos operários baseado na produção de uma linguagem comum a partir do diálogo e de uma não separação entre o econômico, o político e o cultural. De acordo com Debord (2003, p. 145), e os situacionistas de modo geral, a existência do poder dos conselhos operários dependeria de lutas sociais que teriam o cotidiano como foco de um processo de transformação revolucionária. Segundo um texto redigido por ele e publicado na revista da Internacional Situacionista: "A vida cotidiana é a medida de tudo; da realização - ou melhor, da não-realização - das relações humanas, da utilização do tempo vivido; da pesquisa na arte; da política revolucionária".

A transformação revolucionária da vida cotidiana é inseparável da luta contra o poder espetacular difuso: o poder das empresas capitalistas disseminado socialmente mediante a produção de espetáculos e a expropriação do tempo e do espaço.

Na sociedade do espetáculo, o tempo social é o tempo da produção econômica, fragmentado, homogêneo, reduzido à dimensão quantitativa e atuante mundialmente por intermédio das empresas: "O tempo da produção econômica, recortado em fragmentos abstratos iguais, se manifesta por todo o planeta como o mesmo dia. O tempo irreversível unificado é o do mercado mundial e, corolariamente, do espetáculo mundial (DEBORD, 1997, p. 101, grifo do autor).

A possibilidade de um controle do uso do tempo pelos indivíduos é inviabilizada na sociedade capitalista do espetáculo, pois esta promove a sua mercantilização:

O tempo que tem a sua base na produção de mercadorias é ele próprio uma mercadoria consumível, que reúne tudo o que anteriormente se havia diferenciado, durante a fase de dissolução da velha sociedade unitária, como vida privada, vida econômica, vida política. Todo o tempo consumível da sociedade moderna vem a ser tratado como matéria-prima de novos produtos diversificados que se impõem no mercado como empregos socialmente organizados do tempo [...]. 
Por isso, na economia em expansão dos "serviços" e dos lazeres pode aparecer a expressão "pagamento com tudo incluído" para o hábitat espetacular, os pseudodeslocamentos coletivos das férias, as assinaturas do consumo cultural e a venda da própria sociabilidade sob a forma de "conversas animadas" e de "encontros com personalidades". (DEBORD, 1997, p. 104-105)

Debord diferencia o tempo pseudocíclico da sociedade capitalista do tempo efetivamente cíclico, baseado na ordem natural, das sociedades de base agrária:

O tempo pseudocíclico é o do consumo da sobrevivência econômica moderna, a sobrevivência ampliada. Nele, o vivido cotidiano fica privado de decisão e submetido, já não à ordem natural, mas à pseudonatureza desenvolvida no trabalho alienado; esse tempo, portanto, reencontra naturalmente o velho ritmo cíclico que regulava a sobrevivência das sociedades pré-industriais. O tempo pseudocíclico não só se baseia nos traços naturais do tempo cíclico mas também cria novas combinações homólogas: o dia e a noite, o trabalho e o descanso semanais, a volta do período de férias. (DEBORD, 1997, p. 104, grifo do autor)

A apropriação do tempo pela burguesia, dentro do contexto do exercício do poder espetacular difuso, significa o esvaziamento da historicidade mediante a produção pelos meios de comunicação de pseudoacontecimentos, logo substituídos por outros pseudoacontecimentos. A própria temporalidade do que é efetivamente vivido pelos indivíduos é esvaziada, pois não possui lugar na representação espetacular (mercantilizada) da vida:

Como outro lado da deficiência da vida histórica geral, a vida individual ainda não tem história. Os pseudo-acontecimentos que se sucedem na dramatização espetacular não foram vividos por aqueles que lhes assistem; além disso perdem-se na inflação de sua substituição precipitada, a cada pulsão do mecanismo espetacular. Por outro lado, o que foi realmente vivido não tem relação com o tempo irreversível oficial da sociedade e está em oposição direta ao ritmo pseudocíclico do subproduto consumível desse tempo. Esse vivido individual da vida cotidiana separada fica sem linguagem, sem conceito, sem acesso crítico ao seu próprio passado, não registrado em lugar algum. Ele não se comunica. É incompreendido e esquecido em proveito da falsa memória espetacular do não-memorável. 
O espetáculo, como organização social da paralisia da história e da memória, do abandono da história que se erige sobre a base do tempo histórico, é a falsa consciência do tempo. (DEBORD, 1997, p. 107-108, grifo do autor)

A ausência de expressão do tempo e das experiências efetivamente vividas, que são substituídas pelas imagens espetaculares, significa que a temporalidade só sobrevive enquanto ideologia.

A apropriação do tempo pela burguesia, por intermédio da atuação das empresas capitalistas, é complementada pela apropriação do espaço, também pelas práticas capitalistas. Acontece igualmente aqui um esvaziamento do que é qualitativo, substituído pelo quantitativo, pelo homogêneo, pela padronização:

A produção capitalista unificou o espaço, que já não é limitado por sociedades externas. Essa unificação é ao mesmo tempo um processo extensivo e intensivo de banalização. A acumulação das mercadorias produzidas em série para o espaço abstrato do mercado, assim como devia romper as barreiras regionais e legais e todas as restrições corporativas da Idade Média que mantinham a qualidade da produção artesanal, devia também dissolver a autonomia e a qualidade dos lugares. Essa força de homogeneização é a artilharia pesada que fez cair todas as muralhas da China. (DEBORD, 1997, p. 111, grifo do autor)

O urbanismo, ainda segundo Debord, é um instrumento decisivo para a transformação do espaço em cenário da sociedade capitalista e para a luta que a burguesia promove contra a possibilidade de organização dos trabalhadores:

A sociedade que modela tudo o que a cerca construiu uma técnica especial para agir sobre o que dá sustentação a essas tarefas: o próprio território. O urbanismo é a tomada de posição do ambiente natural e humano pelo capitalismo que, ao desenvolver sua lógica de dominação absoluta, pode e deve agora refazer a totalidade do espaço como seu próprio cenário [...]. O urbanismo é a realização moderna da tarefa permanente que salvaguarda o poder de classe: a manutenção da atomização de trabalhadores que as condições urbanas de produção tinham perigosamente reunido. (DEBORD, 1997, p. 112-113, grifo do autor) 
Mas, se a atomização dos trabalhadores é uma necessidade do ponto de vista político, ela precisa ser parcialmente revista, tanto da perspectiva da produção quanto do consumo de mercadorias:

\begin{abstract}
Mas o movimento geral do isolamento, que é a realidade do urbanismo, deve conter também uma reintegração controlada dos trabalhadores, segundo as necessidades planificáveis da produção e do consumo. A integração no sistema deve recuperar os indivíduos isolados como indivíduos isolados em conjunto: as fábricas e os centros culturais, os clubes de férias e os "condomínios residenciais" são organizados de propósito para os fins dessa pseudocoletividade que acompanha também o indivíduo isolado na célula familiar: o emprego generalizado de aparelhos receptores da mensagem espetacular faz com que esse isolamento seja povoado pelas imagens dominantes, imagens que adquirem plena força por causa desse isolamento. (DEBORD, 1997, p. 113-114, grifo do autor)
\end{abstract}

Ainda que o conceito do poder espetacular difuso não esteja, de modo geral, presente nos textos situacionistas sobre a vida cotidiana, o seu conteúdo está presente. A revolução defendida nestes textos implica na destruição desta forma de poder, como se pode ler em um texto redigido por Debord em 1961, publicado na revista da Internacional Situacionista:

\begin{abstract}
A próxima tentativa do movimento revolucionário, radicalizado pelas lições dos anteriores fracassos, e cujo programa reivindicatório deverá enriquecer-se na proporção dos poderes práticos da sociedade moderna poderes que desde já constituem virtualmente a base material que faltava às correntes chamadas utópicas do socialismo -, essa próxima tentativa de total contestação do capitalismo saberá inventar e propor um outro uso da vida cotidiana, e logo se apoiará em novas práticas cotidianas, em novos tipos de relações humanas. (DEBORD, 2003, p. 151)
\end{abstract}

Tendo em vista a dimensão central que a questão do espaço urbano ocupa em Debord, seu foco está no questionamento da apropriação empresarial deste espaço, com a disseminação das relações cotidianas marcadas pelo consumo das mercadorias e na problematização da expropriação do tempo livre, que é direcionado para este consumo. Coerente com a sua filiação à teoria crítica, que se inspira nos argumentos de Lukács presentes em História e consciência de classe (1974), ele 
privilegia, na sua crítica ao capitalismo, o processo de mercantilização de todas as dimensões da vida social. Trabalhando com a teoria dialética das mediações, ele articula sempre o econômico, o político e o ideológico, para afirmar a centralidade do espetáculo na sociedade capitalista do século XX. Tendo em vista o objetivo de compreender o capitalismo como uma totalidade, que só pode ser revolucionada integralmente, o foco da visão de Debord sobre a presença de relações de poder na vida cotidiana é o poder das empresas capitalistas sobre a vida cotidiana como um todo.

\section{Considerações finais}

O diagnóstico de Debord a respeito da contemporaneidade, período histórico a partir da década de 1980, é o da presença simultânea em escala mundial das duas formas de poder, a concentrada e a difusa, que passaram por um processo de integração. A transformação revolucionária da sociedade capitalista depende, assim, de uma luta social contra o crescimento do poder do Estado e também do poder das empresas.

Esse entendimento a respeito do que é uma revolução não encontra correspondência com o pensamento de Arendt, ainda que ambos defendam o papel revolucionário do diálogo em espaços públicos, como os conselhos operários. Arendt questiona teórica e politicamente a noção de totalidade, defendendo a separação entre as diferentes dimensões da vida social, reduzindo a revolução a um processo que seria especificamente político. Debord, pelo contrário, incorpora a cultura ao processo revolucionário, defendendo a não separação entre a arte e a vida, e a fusão entre o trabalho e a dimensão lúdica. Quanto a isto, o máximo que podemos perceber no pensamento de Arendt é a aproximação entre a política, voltada para a ação e a criação do que não existe, e as artes performáticas.

Por outro lado, não há como não reconhecer que a visão de Arendt, a respeito da separação entre poder e violência (dominação), possibilita uma reflexão mais detalhada do que a presente em Debord, a respeito das características do exercício do poder em uma sociedade efetivamente pós-capitalista. 
O contraponto entre experiência e representação ideológica presente no pensamento de Debord e de Arendt é, sem dúvida, de grande atualidade, se quisermos compreender a realidade contemporânea, marcada pelo retorno de ideologias totalitárias, mas também pela atuação de ideologias empresariais, que não só procuram direcionar o comportamento dos indivíduos, reduzidos à condição de consumidores, como procuram substituir ideologias mais explicitamente políticas, com o lançamento de candidaturas e de partidos políticos que defendem a lógica empresarial como a única capaz de governar o Estado. Aqui, o pensamento de Arendt mostra os seus limites, pois não serve de base para um reconhecimento do poder das empresas. Por sua vez, o entendimento de Debord sobre o poder espetacular integrado, quando não haveria um líder único e uma ideologia também única, parece insuficiente para uma compreensão do papel atualmente desempenhado pelas lideranças políticas e pelas ideologias políticas.

De todo modo, fica o desafio de refletirmos sobre situações concretas a partir do pensamento de Arendt e Debord. Apenas com o intuito de contribuição para esta reflexão finalizamos o artigo argumentando que o entendimento de Arendt sobre a substituição do senso comum por um processo de superideologização mostra-se muito pertinente para a compreensão, no contexto brasileiro, do que tornou possível a eleição de Bolsonaro, em especial o papel desempenhado pelas redes sociais virtuais. O entendimento de Debord de que há na contemporaneidade um processo simultâneo de fortalecimento do poder do Estado e das empresas também é bastante pertinente para a compreensão da atuação do Governo Bolsonaro que, ao mesmo tempo, promove "reformas" que retiram direitos dos trabalhadores, favorecendo os interesses empresariais, e fortalece a dimensão repressiva do poder do Estado, com a apologia da violência policial desprovida de limites legais. Resta saber se a intenção bolsonarista de criar um partido político dotado de uma ideologia explicitamente fascista, voltado para uma concentração de poder em torno do Estado e do seu Líder Máximo ("Mito"), não entrará em choque com o poder exercido pelos empresários, que, no final das contas, são a classe dominante e, de modo geral, não têm interesse em ceder poder para uma 
camada burocrática de militantes partidários, mas sobre isto é o futuro quem dará o veredito.

\section{Referências}

AQUINO, J. E. Linguagem e reificação em Guy Debord. Fortaleza: Universidade Estadual do Ceará, 2006.

ARENDT, H. Crises da república. São Paulo: Perspectiva, 1973.

ARENDT, H. Entre o passado e o futuro. São Paulo: Perspectiva, 1979.

ARENDT, H. A condição humana. Rio de Janeiro: Forense Universitária, 1981.

ARENDT, H. Da revolução. São Paulo: Ática, 1988.

ARENDT, H. Origens do totalitarismo. São Paulo: Companhia das Letras, 1989.

DEBORD, G. A sociedade do espetáculo: comentários sobre a sociedade do espetáculo. Rio de Janeiro: Contraponto, 1997.

DEBORD, G. E. Perspectivas de modificações conscientes na vida cotidiana. In: JACQUES, P. B. (org.). Apologia da deriva: escritos situacionistas sobre a cidade. Rio de Janeiro: Casa da Palavra, 2003. p. 143-152.

HABERMAS, J. O conceito de poder em Hannah Arendt. In: FREITAG, B.; ROUANET, S. P. (org.). Habermas: sociologia. São Paulo: Ática, 1980. p. 100-118. (Grandes Cientistas Sociais, v. 15). 
INTERNACIONAL SITUACIONISTA. Contribuição para uma Definição Situacionista de Jogo. In: JACQUES, P. B. (org.). Apologia da deriva: escritos situacionistas sobre a cidade. Rio de Janeiro: Casa da Palavra, 2003. p. 60-61.

JARDIM, E. Hannah Arendt: pensadora da crise e de um novo início. Rio de Janeiro: Civilização Brasileira, 2011.

LUKÁCS. G. História e consciência de classe. Porto: Escorpião, 1974.

Submetido em: 18 dez. 2019 | aprovado em: 18 maio 2020 